\title{
Detection and Quantification of Sulfate-Reducing and Polycyclic Aromatic Hydrocarbon-Degrading Bacteria in Oilfield Using Functional Markers and Quantitative PCR
}

\author{
Nasser B ${ }^{1}$, Ramadan AR ${ }^{2}$, Hamzah RY ${ }^{3}$, Mohamed ME ${ }^{1}$ and Ismail WA ${ }^{2^{*}}$
}

${ }^{1}$ Research and Development Center, Saudi Aramco, Dahrhan, Kingdom of Saudi Arabia

${ }^{2}$ Environmental Biotechnology Program, Department of Life Sciences, College of Graduate Studies, Arabian Gulf University, Manama, Kingdom of Bahrain

${ }^{3}$ College of Sciences, University of Bahrain, Manama, Kingdom of Bahrain

\begin{abstract}
Oilfield water samples from injection water treatment facility and soil/sludge samples from Gas Oil Separation Plant (GOSP) at Saudi Aramco were analyzed for the presence of sulfate-reducing bacteria (SRB) and polycyclic aromatic hydrocarbon (PAH)-degrading bacteria. SRB were detected by targeting a fragment of the apsA gene encoding adenosine-5-phosphosulfate reductase, which is characteristic of all SRB. The PAH-degrading bacteria were detected using a primer pair that amplifies a fragment of the gene encoding the large subunit of the naphthalene dioxygenase gene nahA. The nahA gene was detected in almost half of the soil/sludge samples with the highest copy number of $60540 \mathrm{copies/g}$ soil/sludge. Most of the analyzed water samples contained high copy numbers of nahA gene with the highest copy number 3846 copies $/ \mathrm{mL}$. Most of the analyzed water samples revealed the presence of high copy numbers of the apsA gene with the highest copy number of $44 \times 10^{6} / \mathrm{ml}$ in sample number 2 . Only 7 of the soil/sludge samples revealed the presence of the apsA gene with the highest copy number of 107920/g soil/sludge in sample number 11 . In contrast to the nahA gene, the highest copy numbers of the apsA gene were detected in the water samples. SRB and PAH-degrading bacteria exist in some Saudi oilfields and appear to play a role in the $\mathrm{H}_{2} \mathrm{~S}$ production and $\mathrm{PAH}$ degradation.
\end{abstract}

Keywords: Oilfield; Corrosion; Petroleum; apsA; Naphthalene Dioxygenase

\section{Introduction}

Petroleum biotechnology can be envisaged throughout the value chain of an oil company, starting from exploration and passing through recovery, transport, refining, fine chemicals production, waste treatment/valorization, as well as pollution control (bioremediation). It exploits the astonishing metabolic capabilities of a variety of dedicated microorganisms [1,2]. The latter include sulfate-reducers, hydrocarbon-degrading/transforming, biosurfactants-producing bacteria, etc $[3,4]$. Sulfate-reducing bacteria (SRB) constitute a group of anaerobic microbes, which utilize sulfate as a terminal electron acceptor for the degradation of organic compounds. SRB are widely distributed in anoxic environments where they contribute to the sulfur and carbon cycles [5]. They constitute a unique physiological group of microorganisms encompassing around 220 species of 60 genera [6]. The significance of SRB in the environment and oil industry originates from their sulfidogenic activity, which leads to the production of high levels of biogenic $\mathrm{H}_{2} \mathrm{~S}$ that causes corrosion and souring in oil fields, reduces oil quality, and threatens workers' heath due to its toxicity $[7,8]$. However, SRB can be beneficial where they remove sulfate and heavy metals, and can be applied in bioremediation of subsurface habitats contaminated with toxic metals, BTEX, polychloroethens, trinitrotoluene, etc $[6,9]$. Many recent reports have shown the potential use of SRB metabolites in enhanced oil recovery [10].

Another group of microorganisms, which is important in petroleum and environmental biotechnology applications, is represented by the aromatic hydrocarbons-degrading/transforming bacteria. Bacteria that can completely degrade or only transform polyaromatic hydrocarbons $(\mathrm{PAH})$ are of particular interest due to the recalcitrance of PAH and accumulation in the environment $[11,12]$. Therefore, PAH-degraders can be applied for bioremediation of ecosystems polluted with crude oil or PAH. Moreover, they can be adopted for biological upgrading of heavy crude oil and refinery residues, which contain high proportions of aromatic compounds and asphaltenes, as well as for microbial enhanced oil recovery $[5,11,13]$. PAH-degrading bacteria can be isolated from oilfields and ecosystems polluted with $\mathrm{PAH}$, crude oil, and fuels. They might also inhabit pristine niches.

To exploit the capabilities of microbes for a specific application, it is essential to understand their ecology and physiology sufficiently. Direct enrichment and isolation of relevant microorganisms from various environmental samples have been routinely adopted. However, culture dependent methods underestimate the microbial diversity in nature. Only a small proportion of viable microorganisms in most environmental samples can be recovered by culturing techniques. Moreover, culture-dependent methods are laborious and time consuming. To the contrary, culture-independent methods (molecular tools) based on DNA technology offer many advantages over the culture-dependent methods. They are fast, specific and can be done in situ $[8,14]$.

Molecular detection of SRB and PAH degraders has been studied

"Corresponding author: Wael A. Ismail, Environmental Biotechnology Program Department of Life Sciences, College of Graduate Studies, Arabian Gulf University, Manama, Kingdom of Bahrain, Tel: +97336146948; Fax: +97317239664, E-mail: waelame@agu.edu.bh

Received October 22, 2017; Accepted November 20, 2017; Published November 27,2017

Citation: Nasser B, Ramadan AR, Hamzah RY, Mohamed ME, Ismail WA (2017) Detection and Quantification of Sulfate-Reducing and Polycyclic Aromatic Hydrocarbon-Degrading Bacteria in Oilfield Using Functional Markers and Quantitative PCR. J Pet Environ Biotechnol 8: 348. doi: 10.4172/21577463.1000348

Copyright: ( 2017 Nasser B, et al. This is an open-access article distributed under the terms of the Creative Commons Attribution License, which permits unrestricted use, distribution, and reproduction in any medium, provided the original author and source are credited. 
Citation: Nasser B, Ramadan AR, Hamzah RY, Mohamed ME, Ismail WA (2017) Detection and Quantification of Sulfate-Reducing and Polycyclic Aromatic Hydrocarbon-Degrading Bacteria in Oilfield Using Functional Markers and Quantitative PCR. J Pet Environ Biotechnol 8: 348. doi: 10.4172/2157-7463.1000348

Page 2 of 7

by many authors using phylogenetic markers (16S rRNA gene) and functional markers (key genes of dissimilatory sulfate reduction for SRB and oxygenases for PAH degraders). For instance, Guan et al. [15] investigated the sulfate-reducing communities in four oil reservoirs using $16 \mathrm{~S}$ rRNA and dissimilatory sulfite reductase genes (dsrAB) genes in clone libraries and nested PCR. The authors found that Desulfobacter and Desulfotomaculum-related sequences were predominant in the four oil reservoirs. The common use of $d s r A B$ as a functional marker for identification of SRB showed that $d s r A B$ richness in many environments is dominated by novel sequence variants and collectively represents an extensive, largely uncharted sequence assemblage [16]. Recently, Colin et al. [17] adopted $16 \mathrm{~S}$ rRNA and $d s r A B$-based T-RFLP to characterize total prokaryotic and sulfate-reducing communities along a gradient from estuarine to marine bay water. The diversity of the naphthalene dioxygenase genes in crude oil-contaminated soil was investigated by Yang et al. [18]. The authors reported spatial variation in the density and diversity of naphthalene dioxygenase genes and the gene abundance correlated positively with the level of the total organic carbon and aromatic hydrocarbons. Also in a recent study, Shahi et al. [19] applied Illumina sequencing and qPCR of functional genes involved in degradation of alkanes and aromatics (alkB, phnAc and $n a h)$ to monitor bioremediation of petroleum-contaminated soil.

In this study, RT-qPCR was adopted to detect and quantify characteristic functional genes of SRB and PAH-degrading bacteria in oilfields of the largest oil producer worldwide, Saudi Aramco. Two key functional genes were selected. The gene aps $A$, which encodes adenosine-5'-phosphosulfate reductase (APS) is characteristic of all SRB. The naphthalene dioxygenase-encoding gene nahA is characteristic of many aerobic $\mathrm{PAH}$-degrading bacteria. Water samples were collected from a pipeline system in which SRB and PAH-degrading bacteria might originate from the oil reservoirs and the injection water. Soil and sludge samples were collected from locations where it is very likely to find SRB and PAH-degraders such as a wastewater treatment plant and a water-oil-gas separation facility.

\section{Materials and Methods}

\section{Bacteria}

Reference strains of sulfate-reducing (Desulfovibrio vulgaris subsp. vulgaris DSMZ 644) and polycyclic aromatic hydrocarbon-degrading bacteria (Mycobacterium vanbaalenii DSMZ 7251) were obtained from Deutsche Sammlung von Mikroorganismen und Zellkulturen (German Collection of Microorganisms and Cell Cultures).

\section{Water and soil/sludge samples}

Different oilfield water samples from injection water treatment facility ( 20 samples, $500 \mathrm{~mL}$ each) and soil/sludge samples (20 samples, $100 \mathrm{~g}$ each) from Gas oil separation plant (GOSP) at Saudi Arabian Oil Company were collected for this study. All samples were collected under aseptic conditions in sterile containers and kept at $4^{\circ} \mathrm{C}$ until processed in the laboratory.

\section{Culture media}

Luria-Bertani (LB) agar and broth media were used for routine culturing and maintenance of bacteria and were prepared according to manufacturer's instructions (Fluka, Switzerland). For cloning experiments, ampicillin $(100 \mu \mathrm{g} / \mathrm{mL})$, IPTG $(1 \mathrm{mM})$, and $\mathrm{x}$-gal $(40 \mu \mathrm{g} /$ $\mathrm{mL}$ ) were added to the LB medium. The LB medium was sterilized by autoclaving and these amendments were added from filter-sterilized stock solutions. Growth medium for SRB was purchased from Wheaton Science Products (Millville, New Jersey, USA).

\section{Preparation of bacterial biomass for extraction of DNA}

For isolation of genomic DNA, the PAH-degrading reference strain was grown in $50 \mathrm{~mL}$ of LB broth and incubated under shaking (180 $\mathrm{rpm})$ at $30^{\circ} \mathrm{C}$. When the culture reached optical density $\left(\mathrm{OD}_{600}\right)$ of around $0.7-0.8$, the cells were harvested by centrifugation at $14000 \mathrm{rpm}$ for $10 \mathrm{~min}$ in a pre-cooled centrifuge (Eppendorf 5417R, Germany). The SRB reference strain was grown in $10 \mathrm{~mL}$ of SRB medium at $35^{\circ} \mathrm{C}-37^{\circ} \mathrm{C}$ until culture turbidity and darkness were obvious. The cells were then harvested by centrifugation at $14000 \mathrm{rpm}$ for $10 \mathrm{~min}$.

\section{Isolation of genomic DNA from the reference strains and total community DNA from water and soil/sludge samples}

The isolation of genomic DNA from bacterial cultures $(20 \mathrm{~mL})$ was achieved by the PowerSoil"DNA Isolation kit (MoBio Laboratories, USA) according to manufacturer's instructions. For isolation of DNA from water samples, $50 \mathrm{~mL}$ of each sample were centrifuged (14000 $\mathrm{rpm}, 10 \mathrm{~min}$ ) and the resulting pellet was used for DNA isolation. For isolation of total DNA from soil and sludge samples, $0.5 \mathrm{~g}$ of homogenized sample was used following the same procedures of the PowerSoil Kit.

\section{Polymerase chain reaction (PCR)}

The detection of SRB was performed by PCR using the primers APS7-F and APS8-R shown in Table 1 . These primers amplify part of the functional gene apsA encoding adenosine- 5 '-phosphosulfate reductase (APS). The latter is a key enzyme of sulfate respiration characteristic of all sulfate-reducing bacteria [20]. PCR conditions were: 5 min at $94^{\circ} \mathrm{C}$ followed by 35 cycles of $30 \mathrm{sec}$ at $94^{\circ} \mathrm{C}, 55 \mathrm{sec}$ at $60^{\circ} \mathrm{C}, 1 \mathrm{~min}$ at $72^{\circ} \mathrm{C}$ and final extension of 7 minutes at $72^{\circ} \mathrm{C}$. The PCR product was run on $1 \%$ agarose gel at $120 \mathrm{~V}$ for $45 \mathrm{~min}$. The $\mathrm{PAH}$-degrading bacteria were detected using the primer pair nahAF and nahAR shown in Table 1. These primers amplify a fragment of the gene encoding the large subunit of the naphthalene dioxygenase gene [21]. PCR conditions were $5 \mathrm{~min}$ at $95^{\circ} \mathrm{C}$ followed by $38 \mathrm{cycles}$ of $1 \mathrm{sec}$ at $95^{\circ} \mathrm{C}, 5 \mathrm{sec}$ at $55^{\circ} \mathrm{C}, 20 \mathrm{sec}$ at $72^{\circ} \mathrm{C}$ and final extension of $2 \mathrm{~min}$ at $72^{\circ} \mathrm{C}$. The PCR product was run on $2 \%$ agarose gel at $120 \mathrm{~V}$ for $45 \mathrm{~min}$. The PCR mixture $(20 \mu \mathrm{L})$ contained $1 \mu \mathrm{L}$ of template DNA, $10 \mu \mathrm{L}$ of PCR Mastermix (Promega), $1 \mu \mathrm{L}$ of each primer $(20 \mathrm{pmol} / \mu \mathrm{L})$ and $7 \mu \mathrm{L}$ of nuclease-free water. The PCR product purification was achieved by using the procedure of QlAquick Nucleotide Removal Kit Protocol (Qiagen, Germany).

\section{Preparation of competent cells of Escherichia coli XL1 blue}

A single colony from LB-agar plate was inoculated into $5 \mathrm{~mL} \mathrm{LB}$ broth and incubated at $37^{\circ} \mathrm{C}$ overnight. Aliquot from this culture $(0.2$ $\mathrm{mL}$ ) was inoculated into $100 \mathrm{~mL} \mathrm{LB}$ broth and incubated at $37^{\circ} \mathrm{C}$ until $\mathrm{OD}_{600}$ of 0.2 (after almost 5 hours). The cells were harvested in sterile tubes by centrifugation $\left(4^{\circ} \mathrm{C}\right)$ for $5 \mathrm{~min}$ at $3000 \times \mathrm{g}$. The cell pellet was resuspended in $125 \mathrm{~mL}$ ice-cold $\mathrm{CaCl}_{2}(50 \mathrm{mM})$ and kept on ice for $20 \mathrm{~min}$. The cells were harvested as before and resuspended in $20 \mathrm{~mL}$ of $\mathrm{CaCl}_{2}$ and kept on ice for 4 hours. Glycerol ( $7 \mathrm{~mL}$ from $50 \%$ stock) was added to the cell suspension and aliquots $(200 \mu \mathrm{L})$ were dispensed into sterile cold Eppendorf tubes and transferred immediately to the freezer $\left(-70^{\circ} \mathrm{C}\right)$. The $\mathrm{CaCl}_{2}$ and glycerol stock solutions were sterilized by autoclaving.

\section{Cloning}

The purified PCR products were cloned with the pGEM-T and pGEM-T Easy Vector Systems from Promega according to manufacturer's instructions. Aliquots from the transformation assays 
Citation: Nasser B, Ramadan AR, Hamzah RY, Mohamed ME, Ismail WA (2017) Detection and Quantification of Sulfate-Reducing and Polycyclic Aromatic Hydrocarbon-Degrading Bacteria in Oilfield Using Functional Markers and Quantitative PCR. J Pet Environ Biotechnol 8: 348. doi: 10.4172/2157-7463.1000348

Page 3 of 7

were plated on LB-agar plates containing ampicillin, IPTG, and X-gal followed by incubation at $37^{\circ} \mathrm{C}$ overnight, and blue-white colony selection. Single white colonies (transformants with recombinant DNA) from the plates were inoculated into LB-broth containing ampicillin and incubated with shaking $(200 \mathrm{rpm})$ overnight at $37^{\circ} \mathrm{C}$. Aliquots from the LB cultures $(0.5 \mathrm{~mL})$ were mixed with $0.5 \mathrm{ml}$ of $50 \%$ glycerol and stored at $-70^{\circ} \mathrm{C}$. Moreover, cells were harvested by centrifugation from $5 \mathrm{~mL}$ of each culture and the cell pellet was used to isolate the plasmid DNA using Qiagen Miniprep Kit. The isolated plasmid DNA was verified by PCR with the primers mentioned previously (Table 1).

\section{Real-time quantitative PCR (RT-qPCR)}

RT-qPCR was performed to detect and quantify SRB and PAHdegrading bacteria in the collected oilfield samples. Initially, several dilutions were prepared from the stock of the isolated DNA of each sample and standard curves were constructed. Absolute qPCR was adopted to determine the copy number of SRB and PAH-degrading bacteria by relating the sample signal to a standard curve. Standard curves were prepared for each strain according to Applied Biosystems guidelines. The standard curves covered the range 10 to $10^{6}$ copies with a log interval. Then, the copy number for each sample was determined using SYBR Green Master Mix (QuantiTect ${ }^{\circledR}$ SYBR $^{\oplus}$ Green PCR, Qiagen) where the PCR assays contained $5 \mu \mathrm{L}$ of DNA (12-95 ng/ $\mu \mathrm{L}), 2 \mu \mathrm{L}$ of SYBR Green Master Mix, $1 \mu \mathrm{L}$ of each primer, and $3 \mu \mathrm{L}$ of nuclease-free water. Roter-Gene cycler 6000 (Qiagen) was used with the following conditions: $15 \mathrm{~min}$ at $95^{\circ} \mathrm{C}$ followed by 45 cycles of 20 sec at $94^{\circ} \mathrm{C}, 30 \mathrm{sec}$ at $60^{\circ} \mathrm{C}, 40 \mathrm{sec}$ in $72^{\circ} \mathrm{C}$ (for SRB), and $15 \mathrm{minu}$ at $95^{\circ} \mathrm{C}$ followed by $45 \mathrm{cycles}$ of $15 \mathrm{sec}$ at $94^{\circ} \mathrm{C}, 30 \mathrm{sec}$ at $60^{\circ} \mathrm{C}, 30 \mathrm{sec}$ at $72^{\circ} \mathrm{C}$ (for PAH degraders). The fluorescence was collected at the end of the extension step in each cycle. The copy number of each sample was determined directly from standard curve with a slope $=\mathrm{ca}-3.0$, and efficiency $(E)=97.9 \%$.

\section{Results}

\section{Isolation of DNA, PCR and cloning}

Genomic DNA was isolated from the reference strains as described under Materials and Methods. This genomic DNA was used as a template to test the validity of the designed primers to amplify a fragment of the apsA gene ( $900 \mathrm{bp}$ ) and a fragment of the large subunit of the naphthalene dioxygenase gene nahA (489 bp). Both PCR products were successfully amplified, purified (Figure 1), and cloned in the pGEM vector (3015 bp). A couple of white colonies were picked up, propagated and the plasmid DNA was isolated. To confirm the presence of the inserts (PCR products), the plasmid DNA was used instead of the genomic DNA as a template in PCR with the same primers used for the amplification. Both PCR products could be amplified from the plasmid DNA. The plasmid containing the apsA gene fragment was given the name $\mathrm{pBA} 2$, while the plasmid containing the dioxygenase gene fragment was designated as pBA1.

\section{Standard curves for $\mathrm{qPCR}$}

Serial dilutions of plasmids pBA1 and pBA2, were prepared and used in RT-qPCR to construct standard curves. The RT-qPCR was performed with the same primers that were used for amplification of the inserts. The standard curves for both plasmids are shown in Figures S1 and S2 in Supplementary Material. Both the reaction efficiencies and the $R$ values indicate the validity of the standard curves.

\section{Detection of the naphthalene dioxygenase gene nahA in the oilfield samples}

Total community DNA was isolated from the collected water and

\begin{tabular}{|c|c|c|}
\hline Primer name & Primer sequence & Expected product size (kb) \\
\hline APS7-F & 5'-CCCYGGCGACTATGT-3' & \multirow{2}{*}{0.9} \\
\hline APS8-R & 5'-TGCGTCCAACCMACG-3' & \multirow{2}{*}{ [21] } \\
\hline nahAF & 5'-GGGYCTKTCCGCYATCAAYAC-3' & \\
\hline nahAR & 5'-GCACATGTCGAGGAAGTCTTC-3' & \\
\hline
\end{tabular}

Table 1: Primers used for detection of SRB and PAH-degrading bacteria.

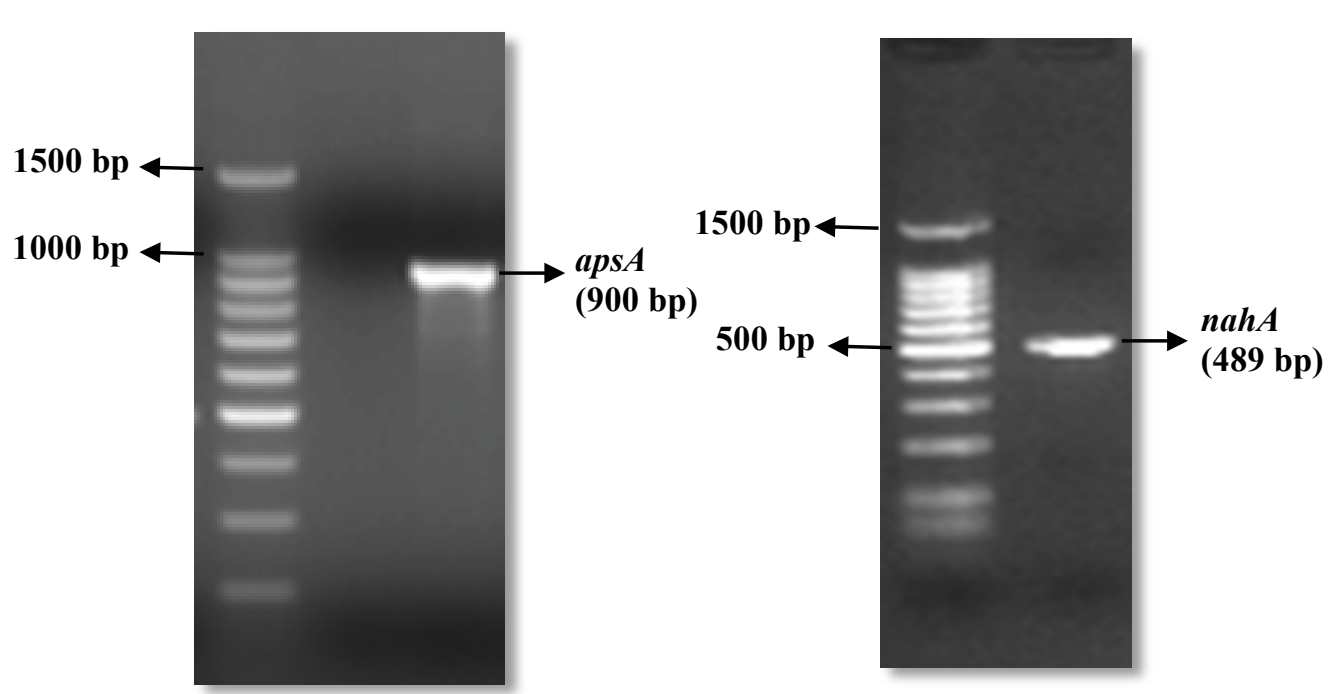

Figure 1: Agarose gel electrophoresis images showing fragments of the apsA and nahA genes amplified from the genomic DNA of the reference strains $D$. vulgaris (DSMZ 644) and M. vanbaalenii (DSMZ 7251), respectively. 
Citation: Nasser B, Ramadan AR, Hamzah RY, Mohamed ME, Ismail WA (2017) Detection and Quantification of Sulfate-Reducing and Polycyclic Aromatic Hydrocarbon-Degrading Bacteria in Oilfield Using Functional Markers and Quantitative PCR. J Pet Environ Biotechnol 8: 348. doi: 10.4172/2157-7463.1000348

Page 4 of 7
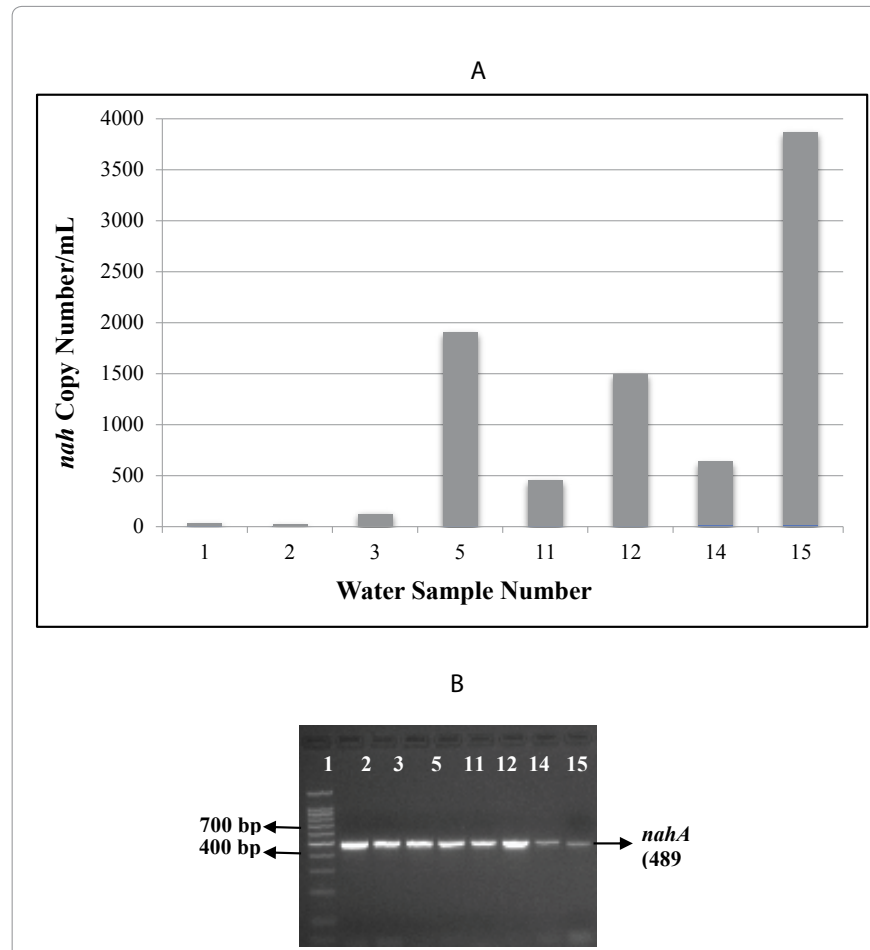

Figure 2: $q P C R$ results for quantification of the nahA gene in the water samples $(A)$ and images of agarose gel electrophoresis showing the amplified PCR products (B).

A

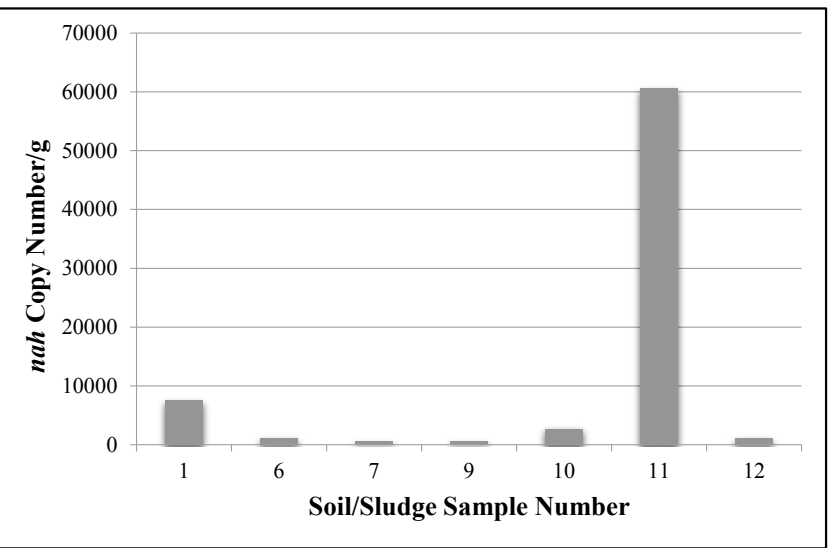

B

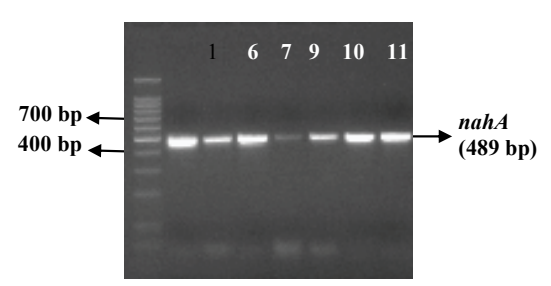

Figure 3: qPCR results for quantification of the nahA gene in the soil/ sludge samples $(A)$ and images of agarose gel electrophoresis showing the amplified PCR products (B).
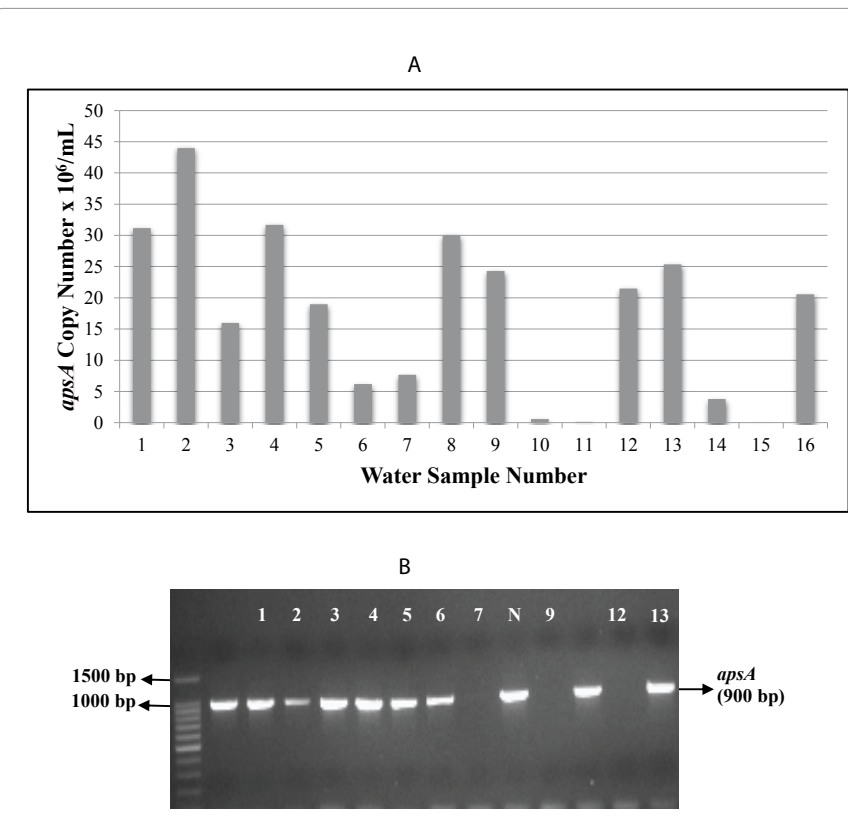

Figure 4: qPCR results for quantification of the apsA gene in the water samples $(A)$ and images of agarose gel electrophoresis showing the amplified PCR products (B).

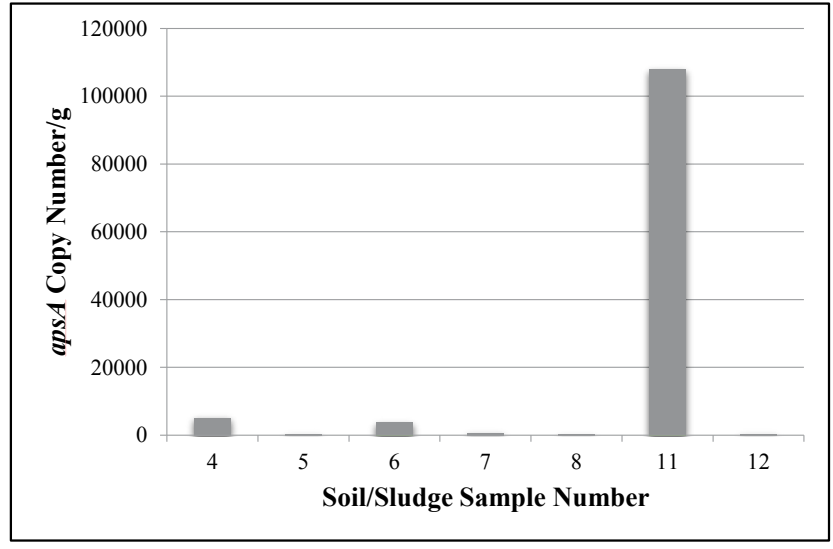

B

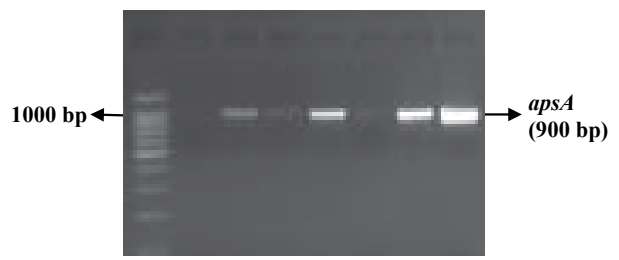

Figure 5: qPCR results for quantification of the apsA gene in the soil/ sludge samples $(A)$ and images of agarose gel electrophoresis showing the amplified PCR products (B)

soil/sludge samples. Only 12 soil/sludge samples out of 20 and 16 water samples out of 20 gave good quality DNA, which was used as a template in RT-qPCR assays with the nahAF and nahAR primers. The results of these assays fitted very well in the standard curve (Figure S3, Supplementary Material). The copy numbers of the nahA gene detected 
Citation: Nasser B, Ramadan AR, Hamzah RY, Mohamed ME, Ismail WA (2017) Detection and Quantification of Sulfate-Reducing and Polycyclic Aromatic Hydrocarbon-Degrading Bacteria in Oilfield Using Functional Markers and Quantitative PCR. J Pet Environ Biotechnol 8: 348. doi: 10.4172/2157-7463.1000348

Page 5 of 7

in the water and soil/sludge samples are shown in Figures 2 and 3. The $n a h A$ gene was detected in 8 of the water samples (Figure 2), whereas the same gene was detected in 7 soil/sludge samples (Figure 3). In general, the copy numbers of nahA gene in the soil/sludge samples were higher than those detected in the water samples. The highest nahA copy number was detected in soil/sludge sample number 11 with 60540 copies/g, whereas the highest copy number of the same gene was detected in water sample number 15 with 3846 copies $/ \mathrm{ml}$.

\section{Detection of the apsA gene in the oilfield samples}

The DNA, which was isolated from the water and soil/sludge samples, was also screened in RT-qPCR assays with the Aps7-F and Aps8-R primers. The results of the assays fitted very well within the standard curve (Figure S4, Supplementary Material). The apsA gene was detected in most of the water samples (Figure 4 ), whereas the same gene was detected in only 7 soil/sludge samples (Figure 5 ). In general, the copy numbers of the apsA gene in the water samples were higher than those detected in the soil/sludge samples. The highest copy number of $44 \times 10^{6} / \mathrm{ml}$ was detected in water sample number 2 (Figure 4 ). For the soil/sludge samples, the highest copy number of the apsA gene (107920 copies/g) was detected in sample number 11 (Figure 5).

\section{Discussion}

In this study, we adopted RT-qPCR for the detection and quantification of SRB and PAH-degrading bacteria in oilfield samples including water and soil/sludge samples. To achieve this goal, we targeted both of the apsA gene, which encodes adenosine-5-phosphosulfate reductase (APS) and is characteristic of all SRB and the naphthalene dioxygenase-encoding gene (nahA), which is characteristic of many aerobic PAH-degrading bacteria. As mentioned earlier, SRB and PAHdegrading bacteria were selected for this study due to their significance in the petroleum and environmental biotechnology fields.

The analyzed water samples showed the presence of high copy number of the apsA gene in most of the samples, which is characteristic for SRB. The presence of high numbers of SRB in injection water treatment facility might be due to better proliferation conditions in the pipeline systems. Formation of biofilms and colonization of pipelines with SRB have been reported in the oil industry $[8,9]$. The presence of high copy numbers of the apsA gene in most of the analyzed water samples suggests that SRB are colonizing the system and could be contributing to the overall internal corrosion of the pipelines. The source of SRB in this pipeline system may be the reservoir (indigenous SRB) or the production water (exogenous SRB) [22]. However, it is difficult to ascertain the origin of these bacteria whether indigenous or exogenous to the oil reservoir. The presence of this high number of SRB mandates the need of pre-treatment of injection water with biocide to mitigate the detrimental consequences of SRB in oil reservoirs.

Due to the prevailing anaerobic conditions in oil reservoirs, it is expected to detect much less of active aerobic microbes in the produced water. The detection of low copy number of $n a h A$ gene $\left(<4 \times 10^{4}\right.$ copies/ $\mathrm{ml}$ ), which is involved in the oxidative degradation of PAH by the aerobic PAH-degrading bacteria, is in line with this expectation. The soil and sludge samples, in contrary to the injection water samples, contained higher numbers of the PAH-degrading nahA gene and less numbers of the SRB apsA gene. The aerobic conditions, the limitation of the terminal electron acceptor $\mathrm{SO}_{4}$ and the proper electron donors in the soil samples, compared with the injection water, might explain the low number of SRB. Generally, the SRB in soil and sludge samples collected from the GOSP might have been originated due to contamination by the produced water or crude oil. The presence of bacteria active in the degradation of $\mathrm{PAH}$ is expected to dominate in soil and sludge samples. This might be due to the prevailing environmental conditions in soil samples, which involve adherence of the less soluble PAH to the soil particles and the availability of oxygen as the preferable electron acceptor. The variability of the copy numbers in the different soil and water samples could be due to the different amounts of DNA used as a template in the qPCR assays. Alternatively, temporal and spatial factors could also be involved.

SRB are ubiquitous and have been detected in many natural and engineered environments where sulfate is available [6]. SRB have been found in hypersaline microbial mats, hydrocarbon seeps, marine sediments, hydrothermal vents, oilfields, deep sub-surface and oil reservoirs [23]. Fingerprint sequences of the dissimilatory sulfite reductase genes $(d s r A B)$ and aps $A$ have been reported by many research groups for investigation of the occurrence, distribution, and diversity of SRB in various environments using various molecular techniques. Geets et al. [24] studied the diversity of SRB in aquifer samples derived from monitoring wells of an in-situ metal precipitation pilot project. The authors used denaturing gradient gel electrophoresis (DGGE) to analyze PCR-amplified sequences of a fragment of the $d s r B$ gene. The sequences of the DGGE bands represented $d s r B$ genes of different SRB-subgroups. Recently, Guan et al. [15] investigated the diversity and distribution of SRB in petroleum reservoirs using $16 \mathrm{~S}$ rRNA and $d s r A B$ genes. The most dominant SRB were those belonging to Desulfotomaculum and Desulfobactor. Also, the diversity of the SRB communities increased while the temperature of the oil reservoirs decreased from $63^{\circ} \mathrm{C}$ to $21^{\circ} \mathrm{C}$. Moreover, Li et al. [25] detected diverse sulfate-reducing bacteria and archaea in production water from high-temperature oil reservoir using high throughput sequencing of phylogenetic markers and RTqPCR for aprA and $d s r A$.

The presence of the nahA gene in many of the analyzed water and soil/sludge samples is a good indication for the presence of PAHdegrading or at least naphthalene-degrading bacteria. These results agree with many publications that reported the isolation of PAH-degrading bacteria from oilfields and petroleum-polluted environments. Zhuang et al. [26] isolated a naphthalene-degrading Bacillus naphthovorans from oil-contaminated tropical marine sediments. The differences in the gene copy numbers between the different samples may reflect temporal and spatial variations between the samples. It is not clear why the copy number in soil sample number 11 is much higher than the corresponding number in the other samples. It is noteworthy that soil sample number 11 also had highest copy number of the aps $A$ gene. Perhaps, the level of contamination was highest at this location and favored the proliferation of PAH-degrading bacteria. The literature comprises a number of investigations on the use of molecular biology techniques for the detection and characterization of $\mathrm{PAH}$-degrading microbial communities. For instance, Debruyn et al. [27] applied qPCR to detect and quantify PAH-degrading bacteria in fresh water sediments using the dioxygenase gene nidA and the 16S rRNA gene as biomarkers. The authors found the nidA gene in all sampling sites with abundance ranging from 2.09 to $70.4 \times 10^{6}$ copies per gram sediment. The highest copy number was detected at the site with the highest level of PAH contamination.

In another study, Cébron et al. [28] applied qPCR to quantify PAHring hydroxylating dioxygenase genes in soil and sediment samples. The functional biomarkers used were genes encoding the $\alpha$-subunit of the multi component PAH-ring hydroxylating dioxygenase from different Gram-positive and Gram-negative bacteria. The authors 
Citation: Nasser B, Ramadan AR, Hamzah RY, Mohamed ME, Ismail WA (2017) Detection and Quantification of Sulfate-Reducing and Polycyclic Aromatic Hydrocarbon-Degrading Bacteria in Oilfield Using Functional Markers and Quantitative PCR. J Pet Environ Biotechnol 8: 348. doi: 10.4172/2157-7463.1000348

Page 6 of 7

detected gene copy numbers that represented $4.4 \times 10^{4}$ to $4.7 \times 10^{7}$ copies per gram soil or sediment. These numbers were detected in the highly contaminated samples. Recently, Yang et al. [29] targeted alkB and nah genes to investigate the abundance and diversity of $n$-alkane and PAH-degrading bacterial communities in soil from oil exploration areas. They found spatial variation in the distribution of alkane and $\mathrm{PAH}$ catabolic genes dependent on environmental variables.

The variations in gene copy numbers between the different samples might reflect differences in the abundance of the corresponding populations (either SRB or PAH degraders). These variations could be due to temporal (date of sample collection) and/or spatial (location of the sample collection) factors. Many biotic and abiotic factors are known to influence the abundance and diversity of microbial populations [29-31]. Hence, it is tempting to propose that samples, which revealed higher gene copy numbers might have higher level of contamination with PAH or naphthalene (in case of the nahA gene) or higher sulfate concentration (in case of the apsA gene). Another parameter, which affects microbial populations, is the presence of competing organisms. Finally, it can't be excluded that numbers of the SRB and PAH-degrading bacteria could be higher than those detected. This is because there are several genotypes of the functional markers that can't be targeted with a single pair of primers as performed in this study. Future investigations should apply deeper sequencing with next generation sequencing techniques coupled to metagenomics to provide a more comprehensive picture of the structural and functional composition of oilfield microbial inhabitants. This can also be supported with metaproteomics and metatranscriptomics.

\section{Conclusion}

Culture-independent qPCR-based molecular technique is an efficient and fast tool that enables the detection and enumeration of environmental microorganisms. It is however, important to include various functional and phylogenetic markers in the detection assays to ensure broad coverage of target microbes. SRB and PAH-degrading bacteria appear to play a role in the souring problem and hydrocarbons degradation of some Saudi oilfields. The detection of the nahA and aps $A$ genes using the primers set involved in this study attest the validity of these primers to fulfill the goal of this study and to develop diagnostic tool for fast identification of problematic microbes such as SRB for risk assessment in oilfield operations.

\section{Acknowledgements}

The authors wish to acknowledge the Saudi Arabian Oil Company (Saudi Aramco) for collecting and offering the oilfield samples as well as for utilizing various lab facilities.

\section{References}

1. Montiel C, Quintero R, Aburto J (2009) Petroleum biotechnology: Technology trends for the future. Afr J Biotechnol 8: 7228-7240.

2. Kotlar HKr, Brakstad OG, Markussen S, Winnberg A (2004) Use of petroleum biotechnology throughout the value chain of an oil company. In: Petroleum Biotechnology: Developments and perspectives. Vazquez-Duhalt R, QuinteroRamirez R (eds) (Studies in Surface Science and Catalysis), Elsevier, Amsterdam. 151: 1-27.

3. Bachmann R, Johnson A, Edyvean R (2014) Biotechnology in the petroleum industry: An overview. Int Biodeterior Biodegradation 86: 225-237.

4. De Almeida DG, Soares Da Silva RC, Luna JM, Rufino RD, Santos VA, et al. (2016) Biosurfactants: Promising molecules for petroleum biotechnology advances. Front Microbiol 7: 1718.

5. Shen Y, Buick R (2004) The antiquity of microbial sulfate reduction. EarthScience Rev 64: 243-272.

6. Muyzer G, Stams, AJ (2008) The ecology and biotechnology of sulphate- reducing bacteria. Nat Rev Microbiol 6: 441-454

7. Voordouw G (2011) Production-related petroleum microbiology: progress and prospects. Curr Opin Biotechnol 22: 401-405.

8. Zhu XY, Lubeck J, Kilbane JJ (2003) Characterization of microbial communities in gas industry pipelines. Appl Environ Microbiol 69: 5354-5363.

9. Barton LL, Fauque GD (2009) Biochemistry, physiology and biotechnology of sulfate-reducing bacteria. Adv Appl Microbiol 68: 41-98.

10. Song W, Ma D, Zhu Y (2014) The role of sulphate-reducing bacteria in oil recovery. Int J Curr Microbiol Appl Sci 3: 385-398.

11. Ghosal D, Ghosh S, Dutta T, Ahn Y (2016) Current state of knowledge in microbial degradation of polycyclic aromatic hydrocarbons (PAHs): A review. Front Microbiol 7: 1369.

12. Habe H, Omori T (2003) Genetics of polycyclic aromatic hydrocarbon metabolism in diverse aerobic bacteria. Biosci Biotechnol Biochem 679: 225-243.

13. Foght JM (2004) Whole-cell bio-processing of aromatic compounds in crude oil and fuels. In: Petroleum Biotechnology: Developments and perspectives, Vazquez-Duhalt R, Quintero-Ramirez R (eds) (Studies in Surface Science and Catalysis), Elsevier, Amsterdam. 151: 145-175.

14. Van Hamme JD, Singh A, Ward OP (2003) Recent advances in petroleum microbiology. Microbiol Mol Biol Rev 67: 503-549.

15. Guan J, Xia LP, Wang LY, Liu JF, Gu JD, et al. (2013) Diversity and distribution of sulfate-reducing bacteria in four petroleum reservoirs detected by using $16 \mathrm{~S}$ rRNA and dsrAB genes. Int Biodeterior Biodegradation 76: 58-66.

16. Müller AL, Kjeldsen KU, Rattei T, Pester M, Loy A (2015) Phylogenetic and environmental diversity of DsrAB-type dissimilatory (bi)sulfite reductases. ISMEJ 9: 1152-1165

17. Colin Y, Goñi-Urriza M, Gassie C, Carlier E, Monperrus M, et al. (2017) Distribution of sulfate-reducing communities from estuarine to marine bay water. Microb Ecol 73: 39-49.

18. Yang Y, Wang J, Liao J, Xie S, Huang Y (2014) Distribution of naphthalene dioxygenase genes in crude oil-contaminated soils. Microb Ecol 68: 785-793.

19. Shahi A, Aydin S, Ince B, Ince O (2016) Evaluation of microbial population and functional genes during the bioremediation of petroleum-contaminated soil as an effective monitoring approach. Ecotoxicol Environ Saf 125: 153-160.

20. Friedrich MW (2002) Phylogenetic analysis reveals multiple lateral transfers of adenosine-5-phosphosulfate reductase genes among sulfate-reducing microorganisms. J Bacteriol 184: 278-289.

21. Nyyssönen M, Piskonen R, Itävaara M (2006) A targeted real-time PCR assay for studying naphthalene degradation in the environment. Microb Ecol 52: 533-543.

22. Gieg LM, Jack TR, Foght JM (2011) Biological souring and mitigation in oil reservoirs. Appl Microbiol Biotechnol 92: 263-282.

23. Magot M, Ollivier B, Patel BK (2000) Microbiology of petroleum reservoirs. Antonie Van Leeuvwenhoek 77: 103-116.

24. Geets J, Borremans B, Diels L, Springael D, Vangronsveld, et al. (2006) DsrB gene-based DGGE for community and diversity surveys of sulfate-reducing bacteria. J Microbiol Methods 66: 194-205.

25. Li XX, Liu JF, Zhou L, Mbadinga SM, Yang SZ, et al. (2017) Diversity and composition of sulfate-reducing microbial communities based on genomic DNA and RNA transcription in production water of high temperature and corrosive oil reservoir.

26. Zhuang WQ, Maszenan AM, Tay ST (2002) Bacillus naphthovorans sp. Nov from oil-contaminated tropical marine sediments and its role in naphthalene biodegradation. Appl Microbiol Biotechnol 58: 547-553.

27. Debruyn JM, Mead TJ, Wilhelm SW, Sayler GS (2009) PAH biodegradative genotypes in Lake Erie sediments: evidence for broad geographical distribution of pyrene degrading mycobacteria. Environ Sci Technol 43: 3467-3473.

28. Cébron A, Norini MP, Beguiristain T, Leyval C (2008) Real-Time PCR quantification of $\mathrm{PAH}-$ ring hydroxylating dioxygenase (PAH-RHDalpha) genes from Gram positive and Gram-negative bacteria in soil and sediment samples. J Microbiol Methods 73: 148-159.

29. Yang Y, Wang J, Liao J, Xie S, Huang Y (2015) Abundance and diversity of soil 
Citation: Nasser B, Ramadan AR, Hamzah RY, Mohamed ME, Ismail WA (2017) Detection and Quantification of Sulfate-Reducing and Polycyclic Aromatic Hydrocarbon-Degrading Bacteria in Oilfield Using Functional Markers and Quantitative PCR. J Pet Environ Biotechnol 8: 348. doi: $10.4172 / 2157-7463.1000348$

Page 7 of 7

petroleum hydrocarbon-degrading microbial communities in oil exploring areas. Appl Microbiol Biotechnol 99: 1935-1946.

30. Gourmelon V, Maggia L, Powell JR, Gigante S, Hortal S, et al. (2016) Environmental and geographical factors structure soil microbial diversity in new caledonian ultramafic substrates: A metagenomic approach. PLoS One 11(12)

31. Wardle DA (2006) The influence of biotic interactions on soil biodiversity. Ecol Lett 9: 870-886. 